\title{
Review \\ Antibody engineering to develop new antirheumatic therapies
} John D Isaacs

\begin{abstract}
Wilson Horne Immunotherapy Centre and Musculoskeletal Research Group, Institute of Cellular Medicine, Newcastle University, Framlington Place, Newcastle-Upon-Tyne, NE2 4HH, UK
\end{abstract}

Corresponding author: John D Isaacs, j.d.isaacs@ncl.ac.uk

Published: 19 May 2009

This article is online at http://arthritis-research.com/content/11/3/225

(c) 2009 BioMed Central Ltd

Arthritis Research \& Therapy 2009, 11:225 (doi:10.1186/ar2594)

\begin{abstract}
There has been a therapeutic revolution in rheumatology over the past 15 years, characterised by a move away from oral immunosuppressive drugs toward parenteral targeted biological therapies. The potency and relative safety of the newer agents has facilitated a more aggressive approach to treatment, with many more patients achieving disease remission. There is even a prevailing sense that disease 'cure' may be a realistic goal in the future. These developments were underpinned by an earlier revolution in molecular biology and protein engineering as well as key advances in our understanding of rheumatoid arthritis pathogenesis. This review will focus on antibody engineering as the key driver behind our current and developing range of antirheumatic treatments.
\end{abstract}

\section{Antibody structure, function, and molecular genetics: a primer}

The biological therapy 'revolution' was made possible by elucidation of the fine detail of the structure-function relationship in immunoglobulin molecules and the 'modular' organisation of the underlying genes. Antibodies are essentially multidomain adapter molecules used by the immune system to neutralise and/or destroy invading microorganisms and their products (antigens). They do this by connecting the antigen with various effector mechanisms. At one end of the antibody molecule (Figure 1), two identical variable (V) regions have a molecular structure that, in three dimensions, is highly complementary to the target antigen. Non-covalent molecular interactions between antibody and antigen ensure a tight fit. The constant $(\mathrm{C})$ region, at the other end of the antibody molecule, determines the fate of the bound antigen.

An antibody comprises four covalently linked polypeptide chains: two identical heavy chains and two identical light chains (Figure 1). The heavy chains usually contain four and the light chain two distinct domains, where a domain is a discrete, folded, functional unit (Figure 2a). The first domain in each chain is the $\mathrm{V}$ domain, $\mathrm{VH}$ and $\mathrm{VL}$ on the heavy and light chains, respectively. The rest of the heavy chain comprises three (four for $\operatorname{lgE}$ ) constant domains $(\mathrm{CH} 1$ to $\mathrm{CH} 3$ ), whilst the light chains have one constant domain (CL). There is a flexible peptide segment (the hinge) between the $\mathrm{CH} 1$ and $\mathrm{CH} 2$ domains.

The antibody $\mathrm{V}$ region is composed of the $\mathrm{VH}$ and $\mathrm{VL}$ domains. The $\mathrm{C}$ region is composed of the $\mathrm{CL}, \mathrm{CH} 1, \mathrm{CH} 2$, and $\mathrm{CH} 3$ domains. Digesting an antibody with papain releases a single $\mathrm{FC}_{\mathrm{C}}$ (fragment crystallisable) fragment corresponding to the $\mathrm{CH} 2$ and $\mathrm{CH} 3$ domains (Figure 2a). Two Fab (fragment antigen-binding) fragments are also generated, corresponding to the antibody binding arms (Figure 2b).

Within each $\mathrm{VH}$ and VL domain, three short polypeptide segments form the hypervariable or complementarity-determining regions (CDRs) (Figure 1). These segments have a highly variable sequence when compared with the rest of the molecule and dictate the precise antigen-binding characteristics of the antibody. The remainder of the $\mathrm{V}$ domain is much less variable and forms a scaffold that supports the CDRs. In the three-dimensional structure of an antibody molecule, the three heavy-chain and three light-chain CDRs are closely apposed to form the antigen-binding site. CDR3 is the most variable of the CDRs and plays a dominant role in antibody specificity. Antibody fragments such as Fab fragments (Figure $2 b$ ), Fvs (non-covalently linked VH and VL domains, Figure 2c), and single-chain Fvs (scFvs) (covalently linked $\mathrm{VH}$ and $\mathrm{VL}$ domains, Figure $2 \mathrm{~d}$ ) generally have the same specificity for antigen as the full-length antibody from which they are derived.

$\mathrm{BLyS}=\mathrm{B}$-lymphocyte stimulator; $\mathrm{C}=$ constant; $\mathrm{CDR}=$ complementarity-determining region; $\mathrm{CH}=$ heavy chain $\mathrm{C}$ domain; $\mathrm{CL}=$ light chain $\mathrm{C}$ domain; $\mathrm{dAb}=$ domain antibody; $\mathrm{Fab}=$ fragment antigen-binding; $\mathrm{Fc}=$ fragment crystallisable; $\mathrm{Fc \gamma R}=$ fragment crystallisable gamma receptor (receptor for the constant region of lgG); Fvs = non-covalently linked heavy and light chain V domains; $\mathrm{mAb}=$ monoclonal antibody; PCR $=$ polymerase chain reaction; RA = rheumatoid arthritis; scFvs = single-chain covalently linked heavy and light chain $V$ domains; $S L E=$ systemic lupus erythematosus; SMIP = small modular immunopharmaceutical; TACl $=$ transmembrane activator and calcium modulator and cyclophilin ligand interactor; $\mathrm{TNF}=$ tumour necrosis factor; $\mathrm{V}=$ variable; $\mathrm{VH}=$ heavy chain $\mathrm{V}$ domain; $\mathrm{VL}=$ light chain $\mathrm{V}$ domain. 
Figure 1

(a)

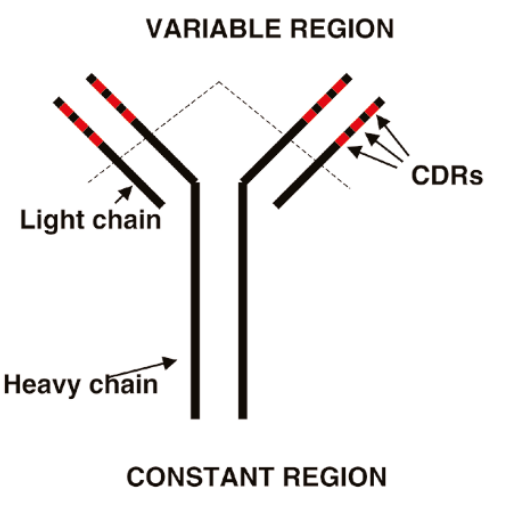

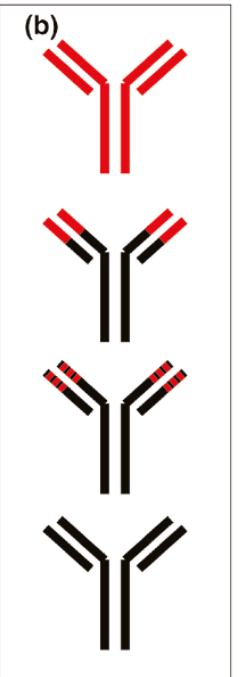

Basic antibody structure and the different types of therapeutic antibody. (a) Basic antibody structure. (b) Basic structure of a murine, chimeric, humanised, and human monoclonal antibody. Red indicates murine sequence and black indicates human sequence. CDR, complementarity-determining region.

The antibody $\mathrm{C}$ region determines the class and subclass of the antibody. There are five human heavy-chain classes (IgM, $\lg G, \lg A, \lg E$, and $\lg D$ ) and two light-chain classes (lambda and kappa). $\lg G$ is the predominant class in blood and tissues and comprises four subclasses, IgG1 to lgG4. Most therapeutic antibodies are lgG molecules. Antibody class and subclass determine the consequences of antibody binding to antigen. $\lg \mathrm{M}, \lg \mathrm{g} 1$, and $\lg \mathrm{G} 3$ activate complement efficiently, leading to chemotaxis and to opsonisation and lysis of the target. IgG1 and IgG3 also have the highest affinity for Fcgamma receptors (FcyR I to III) on white blood cells, resulting in activation of the cells followed by phagocytosis and cellmediated cytotoxicity. $\lg G 2$ and $\lg G 4$ are relatively poor at harnessing effector function, and light-chain class (kappa or lambda) has not been shown to contribute significantly. The neonatal Fc receptor, FcRn, is an important and ubiquitously expressed Fc receptor that, by rescuing IgG molecules from lysosomal degradation, has an important influence on serum half-life [1].

Specific amino acid residues in the $\mathrm{C}$ region of immunoglobulin molecules, particularly in the $\mathrm{CH} 2$ domain, dictate the capacity of certain subclasses to interact with effector mechanisms. For example, residues 318, 320, and 322 are critical for lgG binding to complement C1q and residues 234 to 237 are critical for FcyR binding [2-4]. An asparagine residue at position 297 in $\lg$ molecules is an $\mathrm{N}$-linked glycosylation site that also plays a critical role in effector function [5].
The genetic organisation encoding antibody structure is simultaneously simple and sophisticated, comprising a number of blocks of genes. For a $\mathrm{VH}$ domain, these are as follows:

- V segments, which code for most of the $\mathrm{V}$ domain, including CDRs 1 and 2 and the first part of CDR3,

- D segments that code for the intermediate part of CDR3, and

- J segments that code for the terminal part of CDR3.

In humans, there are about 51 heavy-chain V segments, $25 \mathrm{D}$ segments, and $6 \mathrm{~J}$ segments [6]. During B-cell development, antibody-encoding DNA undergoes various rearrangements (Figure 3). Essentially, any $\mathrm{V}$ segment can fuse to any $\mathrm{D}$ segment and any fused VD segment to any J segment. A similar process occurs in the light chain, where overall there are $71 \mathrm{~V}$ segment and $9 \mathrm{~J}$ segment (but no $\mathrm{D}$ segment) genes. This random pairing of segments (VDJ recombination) leads to a very large number of possible CDR3 sequences, explaining why CDR3 is the most variable CDR. In contrast, the sequences of CDR1 and CDR2 are encoded within the non-rearranged germline antibody sequence. The joins of $\mathrm{V}$ to $\mathrm{D}$ and $\mathrm{D}$ to $\mathrm{J}$ are imprecise, with loss or addition of nucleotides contributing to further CDR3 diversity. Further along the chromosome from the $\mathrm{J}$ segments are the $\mathrm{C}$-region genes in the order $\mathrm{C} \mu$ (encodes IgM heavy chain), $\mathrm{C} \delta$ (encodes $\operatorname{lgD}$ heavy chain), and then the genes for the subclasses of $\lg G$ and $\lg \mathrm{A}$ and for $\lg \mathrm{E}$. Following VDJ recombination, $\lg \mathrm{M}$ or $\lg \mathrm{D}$ antibodies are produced initially, dependent upon RNAprocessing events (Figure 3 ).

After contact with antigen, affinity maturation occurs as a consequence of further mutations within the rearranged immunoglobulin gene. These somatic mutations are concentrated in the CDRs and occur during DNA replication such that the progeny of a $B$ cell produce antibody that is subtly different from that of the parent in terms of affinity for antigen. Those that produce antibody with a higher affinity have a survival advantage over those that do not improve their affinity.

\section{Antibody engineering}

Following the description of monoclonal antibody (mAb) generation by Kohler and Milstein in 1975 [7], increasing knowledge of antibody structure-function relationships and of immunoglobulin gene organisation rendered the production of 'man-made' antibodies conceptually attractive and simple. A number of strategies led up to the 'bespoke' process of antibody design that we are now familiar with.

\section{Chimeric antibodies}

The first therapeutic antibodies were murine proteins produced from murine 'hybridomas' by conventional fusion technology [7]. In rheumatology practice, one of the earliest antiCD4 mAbs was murine [8]. A significant limitation to the use of such 'foreign' molecules was their immunogenicity. For example, OKT3, a murine mAb against human $C D 3$, was 

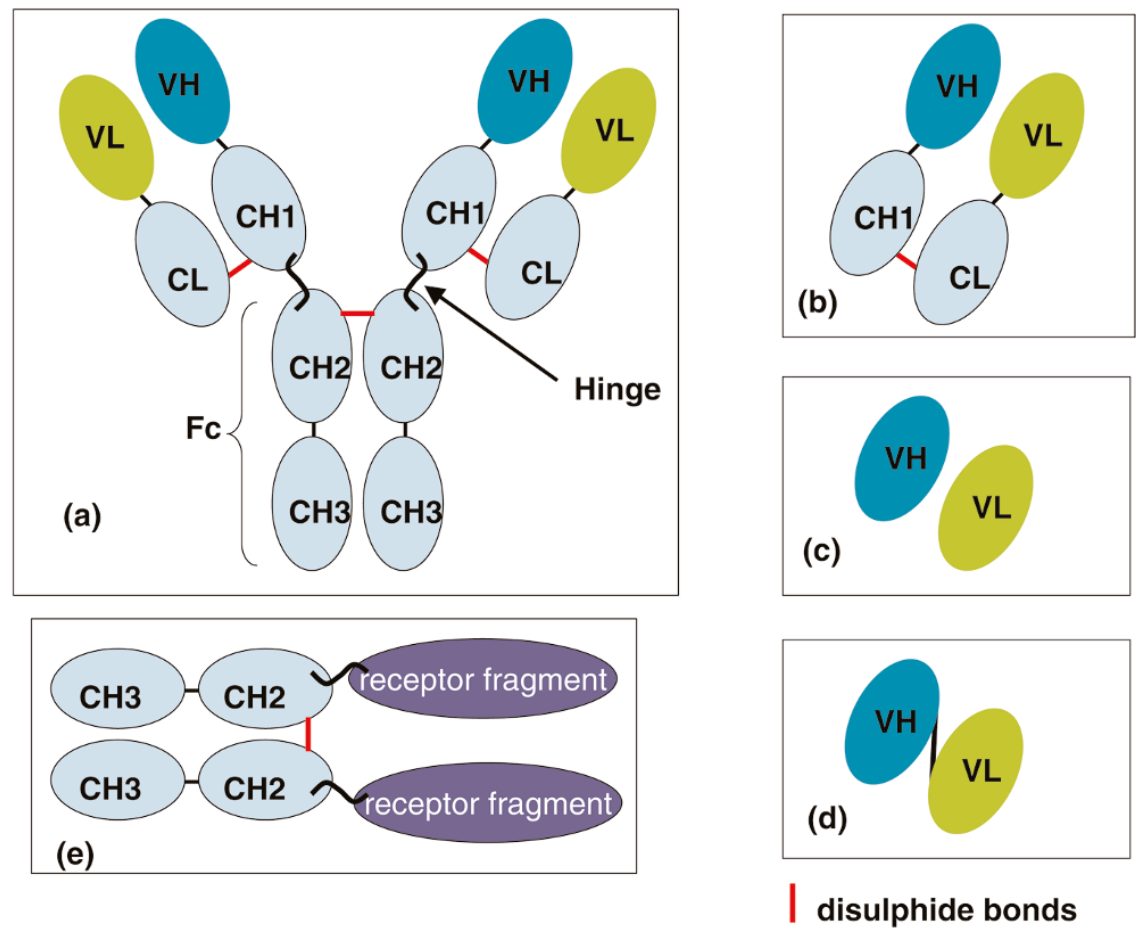

The domain structures of an antibody molecule and its derivatives. (a) An antibody molecule. (b) A fragment antigen-binding (Fab) fragment. (c) A non-covalently linked VH and VL domains (Fv). (d) A single-chain Fv. (e) A receptor-immunoglobulin fusion protein. $\mathrm{CH}$, heavy chain constant domain; $\mathrm{CL}$, light chain constant domain; Fc, fragment crystallisable; $\mathrm{VH}$, heavy chain variable domain; $\mathrm{VL}$, light chain variable domain.

effective for reversing allograft rejection. A subsequent course of therapy was often ineffective, however, due to neutralising anti-antibody - anti-globulin or human anti-murine (HAMA) - responses [9]. A further potential limitation of using murine mAbs was their interaction with human effector functions. There are subtle differences in amino acid sequence between murine and human $\mathrm{Fc}$ regions and between murine and human FcyR. Consequently, the interaction between a murine $\mathrm{mAb}$ and human $\mathrm{Fc \gamma R}$ will be suboptimal, potentially limiting the cytotoxic potential of the antibody in the therapeutic situation.

The modular design of immunoglobulins led to an obvious solution to these issues in the form of chimeric mAbs. Neuberger and colleagues [10] first demonstrated the feasibility of linking a murine antibody V-region gene segment to a human C-region gene segment. The resulting gene construct encoded a chimeric, 'half human/half mouse', mAb (Figure 1b). The chimeric $C$ region did not interfere with antigen binding but, as predicted, dictated the effector function of the encoded mAb. The production of 'matched sets' of chimeric mAbs confirmed the expected inter-class and inter-subclass variation of effector function, enabling the selection of the appropriate $\mathrm{C}$ region for a particular therapeutic task and the birth of 'designer' mAbs [11,12].
Two chimeric mAbs are used in everyday rheumatological practice: infliximab and rituximab (the nomenclature of $m A b s$ is explained in Table 1). Both possess a human IgG1 $\mathrm{C}$ region and these highly effective drugs neutralise tumour necrosis factor-alpha (TNF- $\alpha$ ) and kill B cells, respectively. Nonetheless, their murine $\mathrm{V}$ regions retain the immunogenicity of a foreign protein. The consequences of immunogenicity vary from anaphylaxis, which fortunately is rare, to lack of efficacy and infusion reactions, which are more common. For example, human anti-chimeric antibodies are a significant cause of secondary inefficacy of infliximab, whereby $\mathrm{mAb}$ requirements increase with time and treatment may eventually become ineffective [13]. Infusion reactions are also more frequent in the presence of anti-globulins [14]. A number of factors influence immunogenicity, including background immunosuppression, dose, and route of therapy [15].

\section{Humanised antibodies}

The next significant step in antibody engineering was the process of humanisation. Careful examination of the V-region peptide sequence of a $\mathrm{mAb}$ allows the identification of the CDRs. In the mid-1980s, it was shown that genetic engineering could be used to 'transplant' the CDRs of a murine antibody onto a human V-region framework, generally without a loss of specificity (CDR grafting, Figure 1b) [16]. To 


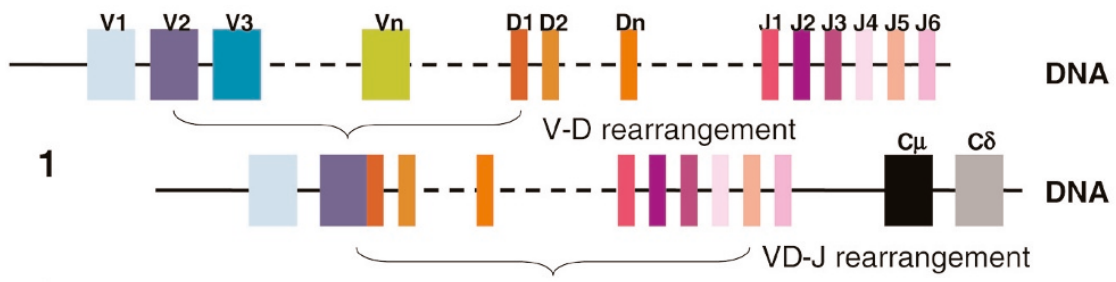

2

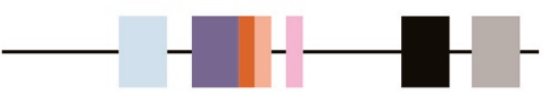

DNA

3

$\downarrow$ transcription

4
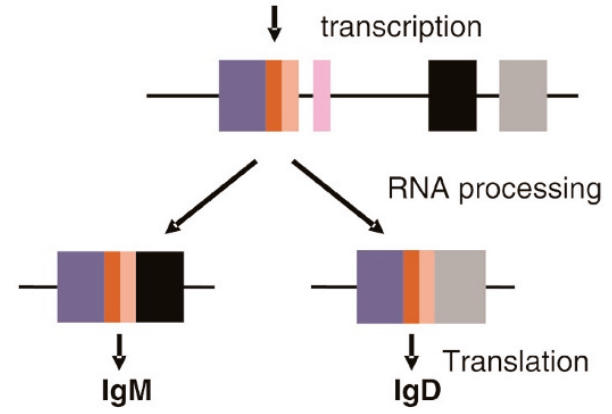

RNA

RNA

Protein

\begin{abstract}
Antibody heavy-chain gene rearrangement, transcription, and translation. In step 1, any $V$ segment (in this case, $V 2$ ) rearranges to any $D$ segment (in this case, D1). In step 2, the VD segment rearranges to one of the six J segments (in this case, J5). Primary RNA transcripts extend from the rearranged VDJ segments through to the $C \delta$ gene (step 3). Finally, RNA processing results in the incorporation of either $C \mu$ or $C \delta$ by the transcripts, encoding for an IgM or IgD antibody, respectively.
\end{abstract}

optimise the 'fit' and ultimate affinity, the chosen human V gene was generally one that closely resembled that of the parent mouse mAb. The main theoretical advantage of humanisation was a further reduction in immunogenicity, although the selected V-region backbone was not always one that was used commonly by the natural human antibody repertoire [17]. In a small study, however, the first humanised therapeutic mAb, CAMPATH-1H (alemtuzumab), was shown to be minimally immunogenic in patients with rheumatoid arthritis (RA) [18]. This drug is highly effective at killing lymphocytes and is now licensed for the treatment of chronic lymphocytic leukaemia whilst continuing to be developed for a number of autoimmune indications. Tocilizumab, a humanised $\mathrm{mAb}$ against the interleukin- 6 receptor that is currently in phase III development for RA, was also developed by CDR grafting, as were ocrelizumab, an anti-CD20 mAb that is currently in phase III trials for RA, and epratuzumab, an anti-CD22 mAb currently being evaluated in systemic lupus erythematosus (SLE) and Sjögren syndrome (Table 1).

A number of techniques have subsequently evolved for generating humanised and 'human' mAbs. Because of their murine CDRs, humanised mAbs theoretically retain a degree of immunogenicity (human anti-human, or HAHA, responses) although trials show this to be relatively low. For a number of reasons, the 'obvious' solution, to generate human hybridomas, was not feasible: it was not appropriate to immunise a human expressly for the generation of a $m A b$, attempts to make
mAbs from venous blood (as opposed to spleen) were unsuccessful or provided low-affinity $\operatorname{lgM} \mathrm{mAbs}$ in small quantities from unstable cell lines, and immunological tolerance provided a significant barrier to raising human mAbs against human targets.

\section{Human antibodies}

In 1989, Orlandi and colleagues [19] showed that it was possible to use the polymerase chain reaction (PCR) to clone immunoglobulin V domains. Subsequently, 'libraries' of immunoglobulin $\mathrm{VH}$ and $\mathrm{VL}$ sequences were created within plasmid and phagemid vectors, allowing the expression of a huge diversity of antibodies [20]. Sequence conservation meant that a relatively small number of 'forward' $\left(3^{\prime}\right)$ and 'backward' $\left(5^{\prime}\right)$ primers could be used to amplify a large proportion of the V-domain repertoire from an appropriate source, including peripheral blood. The incorporation of restriction endonuclease recognition sites into primers facilitated the subsequent in-frame cloning of amplified V-domain sequences.

An extension of the technology allowed the mutation of a cloned $\mathrm{V}$ domain using a number of methods. For example, in 'spiked PCR', the forward primer is synthesised under conditions that introduce low-frequency random mutations, providing a mixed population of many subtly different primers. Because the forward primer encodes CDR3, the resulting PCR product encodes a V-domain mixture with subtly variable CDR3s and hence fine specificities. In contrast, 
Table 1

\begin{tabular}{|c|c|c|c|c|}
\hline mAb category & Suffix & Examples & Specificity & Reference \\
\hline \multirow[t]{2}{*}{ Chimeric } & -ximab & Infliximab (Remicade ${ }^{\circledR}$ ) & TNF- $\alpha$ & [59] \\
\hline & & Rituximab (Rituxan ${ }^{\circledR}$, Mabthera ${ }^{\circledR}$ ) & CD20 & {$[60]$} \\
\hline \multirow[t]{8}{*}{ Humanised } & -zumab & Alemtuzumab (MabCampath ${ }^{\circledR}$ ) & CD52 & [18] \\
\hline & & Tocilizumab (RoActemra ${ }^{\circledR}$ ) & IL-6R & [61] \\
\hline & & Ocrelizumab & CD20 & {$[62]$} \\
\hline & & Epratuzumab & CD22 & [63] \\
\hline & & Certolizumab pegol (PEGylated Fab fragment) (Cimzia ${ }^{\circledR}$ ) & TNF- $\alpha$ & [64] \\
\hline & & Otelixizumab (Aglycosyl) & CD3 & {$[42]$} \\
\hline & & Teplizumab (Fc-mutated) & CD3 & [65] \\
\hline & & Visilizumab (Fc-mutated) & CD3 & [44] \\
\hline \multirow[t]{4}{*}{ 'Fully human' } & -mumab & Adalimumab (Humira ${ }^{\circledR}$ ) & TNF- $\alpha$ & {$[66]$} \\
\hline & & Ofatumumab (Humax-CD20 ${ }^{\circledR}$ ) & CD20 & {$[67]$} \\
\hline & & Belimumab (LymphoStat- $\mathrm{B}^{\circledR}$ ) & BLyS & [68] \\
\hline & & Golimumab & TNF- $\alpha$ & [69] \\
\hline \multirow[t]{3}{*}{ Fusion proteins } & -cept & Etanercept $\left(\right.$ Enbrel $\left.^{\mathbb{\circledR}}\right)$ & TNF- $\alpha$ & {$[70]$} \\
\hline & & Abatacept (Orencia ${ }^{\circledR}$ ) & CD80/CD86 & [71] \\
\hline & & Atacicept & BLyS/BAFF & {$[72]$} \\
\hline
\end{tabular}

BAFF, B-cell activating factor; BLyS, B-lymphocyte stimulator; Fab, fragment antigen-binding; Fc, fragment crystallisable; mAb, monoclonal antibody; TNF- $\alpha$, tumour necrosis factor-alpha.

'error-prone' PCR (using non-stringent amplification conditions or non-proofreading polymerases) results in sequence variability throughout the amplified $\mathrm{V}$ domains. These and similar techniques, when applied to a cloned $\mathrm{V}$ domain, generate variants of altered affinity in a manner analogous to affinity maturation. Other techniques include 'chain shuffling', in which a 'fixed' VH or VL domain is allowed to pair with a library of partner domains, biasing the resulting Fvs toward a desired specificity [21]. Guided selection enabled the derivation of a human mAb starting from a murine sequence [22].

This technology had several advantages. The ability to rapidly capture and clone a significant proportion of the V-domain repertoire from a biological sample was a major advance. Critically, the new technology bypassed the need to use animals for $\mathrm{mAb}$ generation - libraries could be created from human blood samples. Furthermore, because the VH- and VLdomain libraries could be randomly combined and mutated, it became possible to generate specificities absent from the natural repertoire of the source tissue, bypassing immune tolerance mechanisms.

To fully exploit these advances, novel techniques were needed to screen the massive $\mathrm{V}$-domain libraries for desired specificities. Thus, through the use of peripheral blood B cells from a non-immunised individual, PCR amplification might result in $10^{7} \mathrm{VH}$ sequences and a similar number of $\mathrm{VL}$ sequences. Random pairing of these would result in a 'library' of $10^{14}$ different combinations, each cloned into a plasmid. Transformation of a bacterial culture with this library could result in $10^{9}$ distinct Fv specificities (limited largely by transformation efficiency). Phage display technology provided a method for screening such libraries. Filamentous bacteriophages are simple viruses that infect bacteria. They comprise a nucleic acid core and a surrounding protein capsid. By cloning $V$ domains in-frame with specific capsid proteins, the encoded $\mathrm{Fv}$ could be expressed at the phage surface. In particular, functional scFvs (Figure 2d) could be expressed. These molecules comprise a $\mathrm{VH}$ and a $\mathrm{VL}$ joined by a short, flexible, peptide linker. In this way, libraries of $\mathrm{VH}$ and $\mathrm{VL}$ domains could be converted into an antibody fragment phage library, each phage displaying a distinct specificity on its surface $[23,24]$.

Each phage is effectively a 'recombinant genetic display package' expressing an Fv on its surface and containing the encoding DNA within. This physical linking of specificity and DNA provided a major advance. To select phage expressing Fv of desired specificity, it was necessary simply to incubate supernatant from a phage-infected bacterial culture with a solid support (for example, test tube or Petri dish) to which the target antigen was attached, a process termed 'panning'. 
Unbound phage could be washed away, leaving bound phage, a proportion of which was specific for the target antigen. Bound phage then could be eluted and further enriched by infecting a second bacterial culture and repeating the panning process a number of times (Figure 4a). Once an Fv of appropriate specificity and affinity was identified, it could be recloned into a vector containing appropriate $\mathrm{C}$ domains for further drug development. The complex structure of a full $m A b$ required a mammalian cell for its assembly, glycosylation, and secretion, whereas functional fragments such as Fabs could be produced in bacteria.

The ability to produce a 'fully human' mAb of any desired specificity was a major advance over earlier technologies. Adalimumab, a 'fully human' anti-TNF mAb, was developed in this way and is licensed for use both in RA and severe Crohn disease. Belimumab is a $\mathrm{mAb}$ against B-lymphocyte stimulator (BLyS) which was developed using this technology and is in the early phase of development for a number of rheumatic indications (Table 1). Despite the theoretical advantage of fully human mAbs in terms of immunogenicity, however, CDR3 is not germline-encoded by definition. Therefore, this portion of any immunoglobulin molecule is not subject to conventional immune tolerance mechanisms and may remain immunogenic, particularly on repeated administration.

\section{Human immunoglobulin transgenic mice}

A further technique that has significantly contributed to the development of 'fully human' antibodies is the development of mice that are transgenic for the human immunoglobulin locus. These mice have been manipulated such that their endogenous immunoglobulin genes are disrupted and are replaced by their human counterparts $[25,26]$. In some cases, all human immunoglobulin genes have been inserted, including all heavy-chain classes [27]. When these mice are immunised, they produce 'human' antibodies via physiological processes that include affinity maturation. mAbs then can be developed using conventional fusion technology or even phage display technology. Ofatumumab and golimumab, fully human antibodies against CD20 and TNF- $\alpha$, respectively, both currently in phase III development for RA, were derived using this approach (Table 1).

Although a number of 'fully human' therapeutic mAbs have been developed by both phage display and transgenic mouse technology, it is too early to say whether one approach has specific advantages over the other. As highlighted in a recent review [28], phage display may provide a more limited potential repertoire than transgenic mice due to restrictions on antibody expression in bacteria. Furthermore, a higher proportion of mAbs derived from phage display require 'lead optimisation' to improve their affinity, presumably due to the lack of in vivo affinity maturation. However, both types of $\mathrm{mAb}$ have proven clinical efficacy, suggesting that these are complementary technologies with important roles in future mAb development.

\section{Fusion proteins and non-monoclonal antibody entities}

A number of biologics used to treat rheumatological disease are fusion proteins, in which the extracellular domain of a cell surface receptor is fused to part of an immunoglobulin $\mathrm{C}$ region, generally human $\operatorname{lgG} 1$, to create a soluble form of the receptor (Figure $2 \mathrm{e}$ and Table 1 ). Etanercept is the bestrecognised example in rheumatological practice, representing a soluble form of the p75 TNF receptor that inhibits TNF- $\alpha$ activity. The IgG1 $C$ region increases the size and hence the half-life of fusion proteins but potentially also imparts other functions such as complement activation and Fc $\gamma \mathrm{R}$ binding [29]. Abatacept, a fusion protein of CTLA4 and human IgG1, competes with CD28 for binding to CD80 and CD86, thereby interfering with T-cell activation. In this example, the $\mathrm{C}$ region has been mutated to reduce complement activation (see below). Atacicept (TACl-lg) is a soluble form of the transmembrane activator and calcium modulator and cyclophilin ligand interactor (TACl). TACl is a ligand for both BLyS and BAFF (B-cell activating factor) and atacicept therefore neutralises both of these B-cell growth factors, distinguishing it from both belimumab and the BLyS receptor fusion protein, BR3-Fc, which neutralise BLyS only [30]. Thus, fusion proteins are generally simple to design and, as with abatacept and atacicept, can exploit the ligand redundancy of certain receptors, providing a broader specificity than antiligand or anti-receptor mAbs.

The modular design of mAbs provides the template to create completely bespoke therapeutic entities, a concept exploited by Trubion Pharmaceuticals Inc. (Seattle, WA, USA) in the creation of small modular immunopharmaceuticals (SMIPs ${ }^{\mathrm{TM}}$ ). These are single-chain polypeptides that are engineered for full ligand binding and effector function but that are one third to one half the size of a conventional mAb [31]. TRU-015, directed against CD20, comprises an anti-CD20 Fv attached via a linker to an Fc that has been modified to reduce complement activation but to maintain FcyR binding. It is currently undergoing early-phase studies in RA and SLE. The SMIP' ${ }^{\text {тм }}$ technology equally permits the incorporation of receptor fragments in place of an Fv and, for example, toxins in place of an Fc.

Whereas smaller biological entities may require more frequent dosing, potential advantages include improved tissue penetration that, in RA, might provide greater access to inflamed synovium. The smallest antibody fragment drugs currently under development are single $\mathrm{VH}$ or $\mathrm{VL}$ domains (nanobodies ${ }^{\circledR}$ and domain antibodies or $\mathrm{dAbs}^{\mathrm{TM}}$ ) [32-34]. Aside from their small size, potential advantages include ease of production and greatly enhanced stability, potentially allowing oral administration. If required, the half-life of such antibody fragments can be extended using PEGylation or via fusion to an $\mathrm{Fc}$ region. Such an approach was taken for the development of an anti-TNF $\mathrm{dAb}$ that is currently being tested in phase II trials in psoriasis [35]. Dual-specificity agents that neutralise two distinct cytokines simultaneously or bring a 


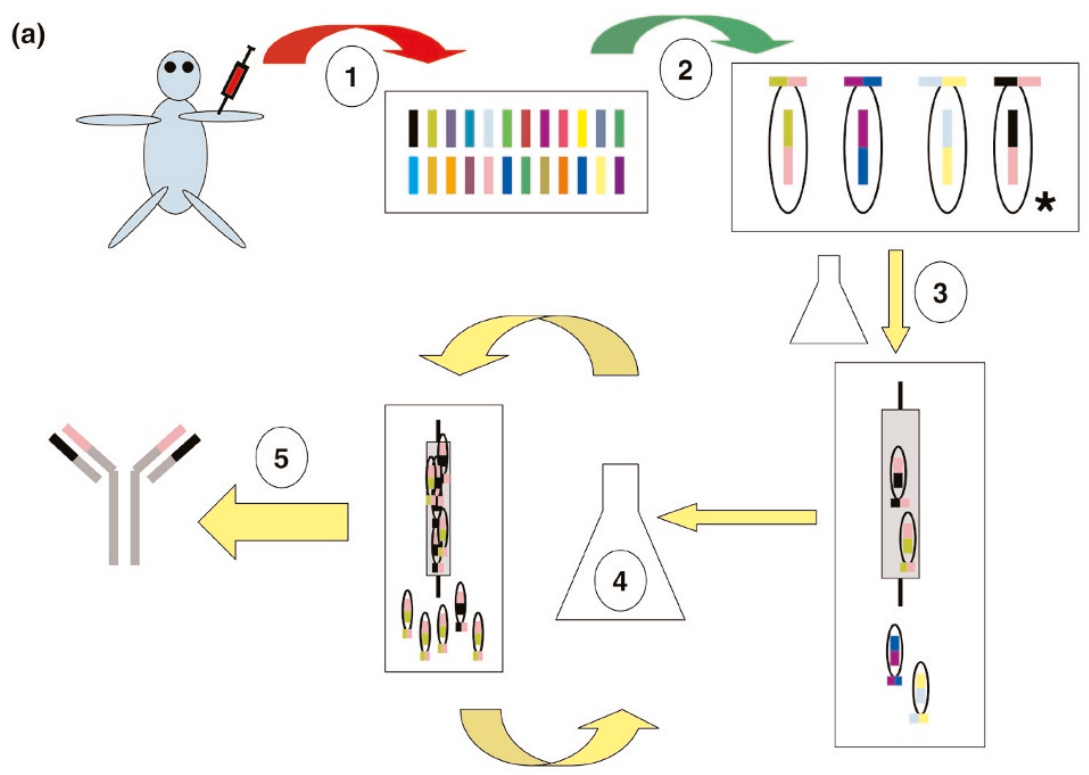

(b)

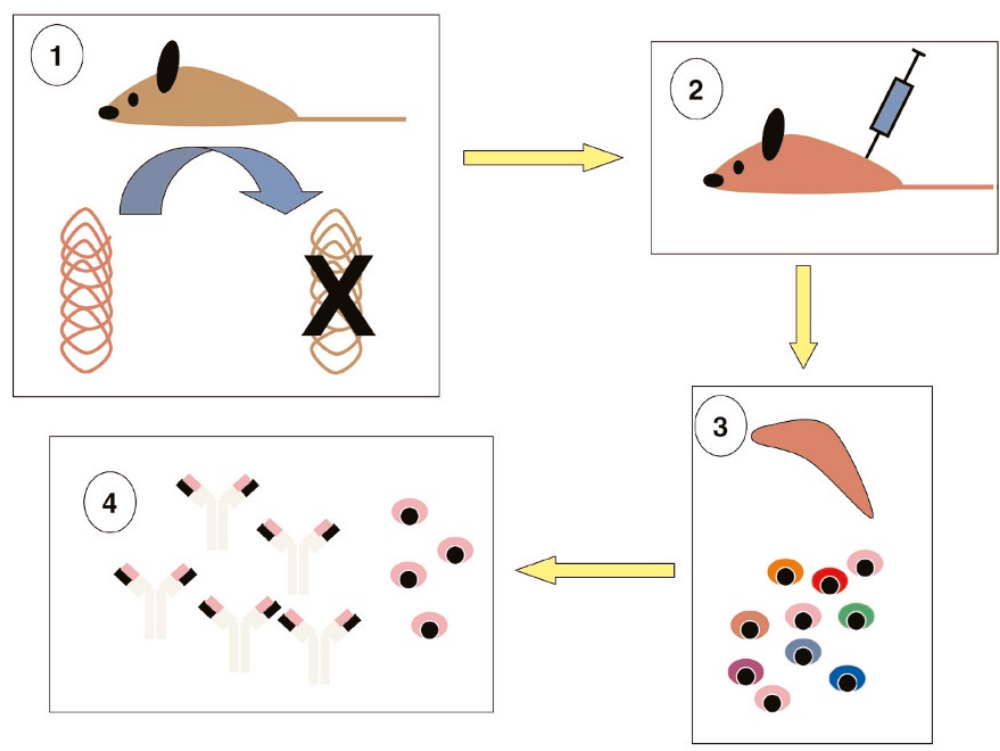

Developing a fully human monoclonal antibody (mAb) using (a) phage display technology and (b) transgenic mouse technology. (a) Step 1: A suitable source of starting material (for example, human blood) is subjected to polymerase chain reaction using appropriate primers, providing 'libraries' of heavy chain V domain (VH) and light chain V domain (VL) sequences. Step 2: Randomly combined VH and VL sequences, connected via a short linker, are incorporated into the genome of a bacteriophage such that they will be expressed at the phage surface. The combination marked with an asterisk encodes the desired specificity. Step 3: The phage library is used to infect a bacterial culture, and the resulting supernatant, containing single-chain Fv-expressing phage particles, is incubated with an appropriate source of target antigen (panning). This can be on a column, Petri dish, and so on. Phage with appropriate specificity adheres to the antigen source. Step 4: Adherent phage is eluted and enriched for the appropriate specificity by further rounds of panning. Step 5: After several rounds of panning, adherent phage is sequenced. A successful procedure should lead to the presence of just one or a few Fv specificities, which can be individually cloned and their specificity checked. At this stage, in vitro affinity maturation procedures can be performed if required (see 'Human antibodies' section for details). Ultimately, the desired specificity is recloned into an appropriate vector containing full-length $\mathrm{mAb}$ sequence for expression in a mammalian cell line. (b) Step 1: A transgenic mouse that produces human antibodies is created by targeted disruption of the endogenous murine immunoglobulin heavy- and light-chain genetic loci and their replacement by the equivalent human sequences. Step 2: The mouse, now containing human immunoglobulin genes, is immunised in a conventional manner using the target antigen. Step 3: Splenocytes from the immunised mouse are used to generate hybridomas via conventional fusion technology. Step 4: Resulting hybridomas are screened, leading to isolation and cloning of a hybridomasecreting high-affinity mAb against the target antigen. Note: In theory, phage display rather than fusion technology can be applied from stage 3 onwards. 
target and effector cell into apposition can also be created. The latter approach was pioneered many years ago in the form of bispecific antibodies [36].

\section{Fc modifications}

For several years, the main focus of biotech activity has been, quite reasonably, the $\mathrm{mAb} V$ region - developing $\mathrm{mAbs}$ with novel specificities or improved affinities. However, the 'downstream' effects of mAbs and fusion proteins, following ligand binding, rely on the $\mathrm{C}$ region/ $\mathrm{Fc}-$ and not all sequelae are desirable. For example, most CD4 mAbs studied in RA trials were profoundly depleting, whereas non-depleting $m A$ Abs were more potent tolerogens in animal models. Similarly, it is thought that complement activation is responsible for some of the infusion-associated adverse effects of mAbs. A profound example of the consequences of FcyR binding was witnessed following the administration of TGN1412 to six healthy volunteers in a phase I clinical trial in 2006 [37]. Massive cytokine release was triggered when the Fc of the 'agonistic' CD28 mAb bound to human FcyR. The isotype of TGN1412 was human $\lg G 4$, which has a lower affinity than $\lg G 1$ for Fc $\gamma R$ and does not activate complement. The lack of interaction between human IgG4 and monkey Fc $\gamma \mathrm{R}$ probably explains why the mAb appeared safe in primate studies.

Engineering of $m A b$ Fcs is now relatively common, following the identification of key residues that underlie both complement and FcyR binding [2-5]. In general, modification is performed to reduce effector function, although it may also be enhanced [38]. For example, the CTLA4-lg $F_{c}$ is mutated to reduce complement activation, which may reduce the incidence of infusion reactions. Certolizumab pegol has a unique structure among mAb therapeutics. It comprises the Fab fragment of a humanised TNF- $\alpha$ mAb conjugated to polyethylene glycol. By definition, this molecule has no Fcrelated functions, acting as a pure TNF- $\alpha$ antagonist. PEGylation increases the half-life of the molecule, which remains smaller than a conventional $\mathrm{mAb}$ [39]. It is efficacious in RA and Crohn disease, which attests to the importance of TNF- $\alpha$ neutralisation in their treatment, without an absolute requirement for $\mathrm{Fc}$-mediated effector mechanisms.

Several engineered CD3 mAbs are currently in development for indications that include psoriatic arthritis and RA. These have been modified to reduce FcyR binding to harness the efficacy of CD3 blockade with reduced side effects. The original murine $\mathrm{CD} 3 \mathrm{mAb}$, OKT3, potently reversed allograft rejection but caused a profound cytokine release syndrome on initial dosing, mediated via FcyR binding [40]. Otelixizumab is a humanised rat $\mathrm{mAb}$ in which asparagine has been replaced by alanine at residue 297 of the human IgG1 Fc. This is the o-linked glycosylation site, where carbohydrate is incorporated into the mAb structure. The mutation therefore creates an aglycosyl $\mathrm{mAb}$ that in vitro and preclinical data suggest has significantly reduced effector function [5], and this has been confirmed by clinical studies in allograft recipients and type-1 diabetics [41,42]. Teplizumab is a humanised Fc-mutated version of OKT3. It has been rendered 'non-mitogenic' by the mutation of two key Fc $\gamma R$ binding residues and has demonstrated efficacy in psoriatic arthritis [43]. A third CD3 mAb with similar properties is visilizumab, although in this case inflammatory bowel disease trials have demonstrated that its efficacy is accompanied by significant first dose-associated cytokine release [44].

Advances in glycobiology have led to an explosion of knowledge around carbohydrate structure-function relationships, which is now being exploited in glyco-engineering. Sugar contributes between $3 \%$ and $12 \%$ of the mass of an immunoglobulin molecule, the precise $\mathrm{Fc}_{\mathrm{C}}$ sugar content and structure influencing effector function $[45,46]$. This can be modified either chemically or by producing $\mathrm{mAbs}$ in cell lines expressing particular sugar-modifying enzymes. For example, a glyco-engineered form of rituximab that has enhanced ADCC (antibody-dependent cellular cytotoxicity) activity has been created [47].

Notwithstanding the above discussion, it is important to recognise the importance of target antigen with respect to $\mathrm{mAb}$ effector function. Even a mAb that potently activates complement and strongly binds Fc $\gamma R$ will not necessarily lyse cells expressing its target antigen. Conversely, some targets are particularly attractive for cell lysis. CD52 is one such target and even a human IgG4 CD52 mAb (IgG4-CAMPATH or lgG4-alemtuzumab) induced profound lymphopenia despite absent complement activation and weak FcyR binding [48]. Similarly, mAbs against distinct epitopes of the same antigen can have widely differing cytotoxic characteristics [49]. The critical features of the target antigen have not been fully defined, but close apposition between $\mathrm{mAb}$ and target cell membrane is a key parameter, as is the case with alemtuzumab and CD52 [50]. Interestingly, alemtuzumab has a relatively low affinity for CD52, demonstrating that high affinity is not required for potent cytotoxicity.

\section{Outstanding issues}

\section{Understanding monoclonal antibody pharmacology}

The uniqueness of mAbs underpins a sometimes enigmatic aspect of their biology. As highlighted in a recent review [15], the 'obvious' mode of action for a mAb is sometimes difficult to substantiate in the clinic. This has been the case particularly for TNF- $\alpha$ mAbs in RA, in which simple neutralisation of soluble TNF- $\alpha$ cannot always explain the observed benefits of therapy. The situation can be even more complex for mAbs with a cell surface target, such as anti-T cell mAbs. A lack of target identity means that the therapeutic mAb cannot usually be tested for biological activity in animal models. In such cases, it may be necessary to develop a surrogate $m A b$ against the mouse or rat homologue to test biological activity in animal models. However, under these circumstances, it may not be possible to extrapolate precisely the expected clinical effects, and consequently, potential 
beneficial and adverse effects cannot necessarily be predicted. Furthermore, the complexities of the immune system render most in vitro models of limited use in terms of predicting effector function; therefore, in vivo biological activity can only be conjectured and, as with anti-CD4 mAbs, often erroneously [15]. Notably, even when the in vivo consequences of TGN1412 administration were apparent, it remained difficult to conceive an in vitro model that predicted the cytokine storm that underpinned its toxicity [51]. There is no simple answer to this issue of predictability, apart from continued careful observation of patients in the clinic alongside experimental medicine studies on their blood and tissues, measuring pharmacokinetics and testing pharmacodynamic hypotheses.

\section{Immunogenicity}

Even fully humanised mAbs retain immunogenicity in some patients. In addition to CDR immunogenicity referred to earlier, inter-individual genetic variation results in immunoglobulin allotypes [52]. These V- and C-region allotypic sequences theoretically can invoke anti-globulin responses in individuals of alternate allotypes [18]. The only human C region that is not allotypic is lgG4 [53]. Therapeutic mAbs are produced from non-human cell lines, and consequently, their carbohydrates also differ from endogenous immunoglobulins. In general, this has not been shown to adversely affect immunogenicity. A recent report, however, demonstrated hypersensitivity to the galactose- $\alpha-1,3-$ galactose moiety on cetuximab, a chimeric $\mathrm{mAb}$ against the epidermal growth factor receptor produced in the SP2/0 mouse cell line [54]. Pre-existing lgE antibodies against this oligosaccharide, which is closely related to substances in the ABO blood group, predisposed to anaphylactic reactions.

\section{Biosimilars}

Equivalent issues are relevant to the concept of 'generic' mAbs or biosimilars. Unlike with small-molecule drugs, it may not be possible to create an identical version of a therapeutic $m A b$. Even different clones of a particular cell line may impart subtle changes on a mAb molecule, and only the original mAb-encoding DNA clone and master cell bank can be guaranteed to generate a consistent product, provided culture conditions are carefully maintained. Even then, subtle modifications to downstream manufacturing processes can result in significant changes to properties such as immunogenicity or even effector function $[55,56]$. Legislation and regulations concerning the development of 'biosimilar' $\mathrm{mAbs}$ remain to be fully defined, but as current patents start to expire, this situation must soon change [57].

\section{Economics}

It is important to recognise that the identification of a potential mAb specificity is only the start of a long and expensive process that may or may not culminate in a marketable and profitable product. Even after mAb-encoding DNA is cloned and characterised and the protein product demonstrates appropriate bioactivity, significant work follows in order to optimise and standardise the manufacturing process. For example, considerable effort is required to define the optimal production cell line and growth conditions for high yields, and downstream purification and formulation processes may also be complex and require precise standardisation. This is reflected in the high cost of most licensed biologic drugs [58].

In contrast to mammalian cell lines, bacteria provide a highly efficient means of mAb production, a fact exploited by certolizumab pegol which is produced in Escherichia coli. This is possible because Fab fragments do not require as much processing by the producer cells as do full-length mAbs: bacterial cells cannot glycosylate nor can they assemble complex multichain macromolecules. A disadvantage of bacterial production is that the downstream process must ensure complete freedom of the final product from bacterial molecules such as endotoxin. Yields are significantly higher, however, and it seems likely that bacterial production processes will be further exploited in the future, particularly in relation to some of the novel $\mathrm{mAb}$ fragments referred to earlier.

\section{Conclusions}

The original $\mathrm{mAb}$ revolution, precipitated by the discovery of fusion technology, has been superseded by an even more profound transformation catalysed by antibody engineering. Indeed, all of the currently licensed biologics used in rheumatological practice, as well as those in development, have been engineered in one way or another. Future advances are likely to involve glyco-engineering and small $\mathrm{mAb}$ fragments, whilst bacterial production processes and biosimilars may provide cheaper therapeutics. This is critical because the current high cost of biologics means that many patients still cannot access these highly effective drugs. From an academic viewpoint, it remains paramount that we continue to study these drugs from an experimental medicine perspective to ensure that we fully understand their capabilities and the potential consequences of their administration to our patients.

\section{7) The Scientific Basis of Rheumatology: A Decade of Progress}

This article is part of a special collection of reviews, The Scientific Basis of Rheumatology: A Decade of Progress, published to mark Arthritis Research \& Therapy's 10th anniversary.

Other articles in this series can be found at: http://arthritis-research.com/sbr 


\section{Competing interests}

JDI has consulted for and/or has served on advisory boards of Bristol-Myers Squibb Company (Princeton, NJ, USA), Medlmmune Limited (formerly known as Cambridge Antibody Technology, Gaithersburg, MD, USA), GlaxoSmithKline (Uxbridge, Middlesex, UK), Genzyme (Cambridge, MA, USA), Roche (Basel, Switzerland), and TolerRx (Cambridge, MA, USA). He is named as co-inventor on a European patent relating to the use of non-mitogenic anti-CD3 $m A b$ in inflammatory arthritis.

\section{References}

1. Junghans RP, Anderson CL: The protection receptor for IgG catabolism is the beta2-microglobulin-containing neonatal intestinal transport receptor. Proc Natl Acad Sci U S A 1996, 93:5512-5516

2. Duncan A, Winter G: The binding site for C1q on IgG. Nature 1988, 332:738-740.

3. Duncan A, Woof J, Partridge L, Burton D, Winter G: Localization of the binding site for the human high-affinity Fc receptor on IgG. Nature 1988, 332:563-564.

4. Lund J, Winter G, Jones PT, Pound JD, Tanaka T, Walker MR, Artymiuk PJ, Arata Y, Burton DR, Jefferis R, Woof JM: Human Fc gamma RI and Fc gamma RII interact with distinct but overlapping sites on human IgG. J Immunol 1991, 147:2657-2662.

5. Isaacs J, Greenwood J, Waldmann $\mathrm{H}$ : Therapy with monoclonal antibodies II. The contribution of Fcg receptor binding and the influence of $\mathrm{Ch} 1$ and $\mathrm{Ch} 3$ domains on in vivo effector function. J Immunol 1998, 161:3863-3869.

6. Lefranc MP, Giudicelli V, Ginestoux C, Bodmer J, Muller W, Bontrop R, Lemaitre M, Malik A, Barbie V, Chaume D: IMGT, the international ImMunoGeneTics database. Nucleic Acids Res 1999, 27:209-212.

7. Kohler G, Milstein C: Continuous cultures of fused cells secreting antibody of predefined specificity. Nature 1975, 256:495-497.

8. Herzog C, Walker C, Pichler W, Aeschlimann A, Wassmer P, Stockinger H, Knapp W, Rieber P, Muller W: Monoclonal antiCD4 in arthritis. Lancet 1987, 8573:1461-1462.

9. Schroeder TJ, First MR, Mansour ME, Hurtubise PE, Hariharan S, Ryckman FC, Munda R, Melvin DB, Penn I, Ballistreri WF, Alexander JW: Antimurine antibody formation following OKT3 therapy. Transplantation 1990, 49:48-51.

10. Neuberger MS, Williams GT, Mitchell EB, Jouhal SS, Flanagan JG, Rabbitts TH: A hapten-specific chimaeric IgE antibody with human physiological effector function. Nature 1985, 314:268270.

11. Bruggemann $M$, Williams $G$, Bindon $C$, Clark $M$, Walker $M$, Jefferis R, Waldmann H, Neuberger M: Comparison of the effector functions of human immunoglobulins using a matched set of chimeric antibodies. J Exp Med 1987, 166:1351-1361.

12. Isaacs J, Clark M, Greenwood J, Waldmann H: Therapy with monoclonal antibodies. An in vivo model for the assessment of therapeutic potential. J Immunol 1992, 148:3062-3071.

13. Wolbink GJ, Vis M, Lems W, Voskuyl AE, de Groot E, Nurmohamed MT, Stapel S, Tak PP, Aarden L, Dijkmans B: Development of antiinfliximab antibodies and relationship to clinical response in patients with rheumatoid arthritis. Arthritis Rheum 2006, 54:711-715

14. Baert F, Noman M, Vermeire S, Van Assche G, Haens G, Carbonez $A$, Rutgeerts $P$ : Influence of immunogenicity on the long-term efficacy of infliximab in Crohn's disease. $N$ Engl $J$ Med 2003, 348:601-608.

15. Strand V, Kimberly R, Isaacs JD: Biologic therapies in rheumatology: lessons learned, future directions. Nat Rev Drug Discov 2007, 6:75-92.

16. Jones PT, Dear PH, Foote J, Neuberger MS, Winter G: Replacing the complementarity-determining regions in a human antibody with those from a mouse. Nature 1986, 321:522-525.

17. Clark M: Antibody humanization: a case of the 'Emperor's new clothes'? Immunol Today 2000, 21:397-402.

18. Isaacs J, Watts R, Hazleman B, Hale G, Keogan M, Cobbold S, Waldmann $\mathrm{H}$ : Humanised monoclonal antibody therapy for rheumatoid arthritis. Lancet 1992, 340:748-752.
19. Orlandi R, Gussow DH, Jones PT, Winter G: Cloning immunoglobulin variable domains for expression by the polymerase chain reaction. Proc Natl Acad Sci U S A 1989, 86: 3833-3837.

20. Persson MA, Caothien RH, Burton DR: Generation of diverse high-affinity human monoclonal antibodies by repertoire cloning. Proc Natl Acad Sci U S A 1991, 88:2432-2436.

21. Marks JD, Griffiths AD, Malmqvist M, Clackson TP, Bye JM, Winter G: By-passing immunization: building high affinity human antibodies by chain shuffling. Biotechnology $(N Y)$ 1992, 10:779-783.

22. Jespers LS, Roberts A, Mahler SM, Winter G, Hoogenboom HR: Guiding the selection of human antibodies from phage display repertoires to a single epitope of an antigen. Biotechnology $(N Y)$ 1994, 12:899-903.

23. Griffiths AD, Williams SC, Hartley O, Tomlinson IM, Waterhouse $\mathrm{P}$, Crosby WL, Kontermann RE, Jones PT, Low NM, Allison TJ, Prospero TD, Hoogenboom HR, Nissim A, Cox JPL, Harrison JL, Zaccolo M, Gherardi E, Winter G: Isolation of high affinity human antibodies directly from large synthetic repertoires. EMBO J 1994, 13:3245-3260.

24. McCafferty J, Griffiths AD, Winter G, Chiswell DJ: Phage antibodies: filamentous phage displaying antibody variable domains. Nature 1990, 348:552-554.

25. Bruggemann M, Caskey HM, Teale C, Waldmann H, Williams GT, Surani MA, Neuberger MS: A repertoire of monoclonal antibodies with human heavy chains from transgenic mice. Proc Natt Acad Sci U S A 1989, 86:6709-6713.

26. Lonberg $\mathrm{N}$ : Human antibodies from transgenic animals. Nat Biotechnol 2005, 23:1117-1125.

27. Medarex - UltiMAb Human Antibody Development System ${ }^{\circledR}$ [http://www.medarex.com/Development/UltiMAb.htm].

28. Lonberg N: Fully human antibodies from transgenic mouse and phage display platforms. Curr Opin Immunol 2008, 20: 450-459.

29. Nesbitt A, Fossati G, Bergin M, Stephens P, Stephens S, Foulkes $R$, Brown D, Robinson M, Bourne T: Mechanism of action of certolizumab pegol (CDP870): in vitro comparison with other anti-tumor necrosis factor alpha agents. Inflamm Bowel Dis 2007, 13:1323-1332.

30. Dillon SR, Gross JA, Ansell SM, Novak AJ: An APRIL to remember: novel TNF ligands as therapeutic targets. Nat Rev Drug Discov 2006, 5:235-246.

31. Trubion Pharmaceuticals, SMIPTM therapeutics [http://www. trubion.com/products/technology/smip-therapeutics/].

32. Ablynx, Nanobody ${ }^{\circledR}$ Platform [http://www.ablynx.com/research/ index.htm]

33. Domantis Limited homepage [http://www.domantis.com].

34. Ward ES, Gussow D, Griffiths AD, Jones PT, Winter G: Binding activities of a repertoire of single immunoglobulin variable domains secreted from Escherichia coli. Nature 1989, 341: 544-546.

35. Arana Therapeutics, ART621 - Phase II Trial Underway [http:// www.arana.com/inflammation_franchise_art621.htm].

36. Milstein C, Cuello AC: Hybrid hybridomas and their use in immunohistochemistry. Nature 1983, 305:537-540.

37. Suntharalingam G, Perry MR, Ward S, Brett SJ, Castello-Cortes A, Brunner MD, Panoskaltsis N: Cytokine storm in a phase 1 trial of the anti-CD28 monoclonal antibody TGN1412. $N$ Engl $J$ Med 2006, 355:1018-1028.

38. Natsume A, In M, Takamura $H$, Nakagawa T, Shimizu $Y$, Kitajima $K$ Wakitani M, Ohta S, Satoh M, Shitara K, Niwa R: Engineered antibodies of IgG1/lgG3 mixed isotype with enhanced cytotoxic activities. Cancer Res 2008, 68:3863-3872.

39. Melmed GY, Targan SR, Yasothan U, Hanicq D, Kirkpatrick P: Certolizumab pegol. Nat Rev Drug Discov 2008, 7:641-642.

40. Chatenoud L, Ferran C, Legendre C, Franshimont P, Reuter A Kreis $\mathrm{H}$, Bach J: Clinical use of OKT3: the role of cytokine release and xenosensitization. J Autoimmun 1988, 1:631-640.

41. Friend PJ, Hale G, Chatenoud L, Rebello P, Bradley J, Thiru S, Phillips JM, Waldmann H: Phase I study of an engineered aglycosylated humanized CD3 antibody in renal transplant rejection. Transplantation 1999, 68:1632-1637.

42. Keymeulen B, Vandemeulebroucke E, Ziegler A, Mathieu C, Kaufman L, Hale G, Gorus F, Goldman M, Walter M, Candon S, Schandene L, Crenier L, De Block C, Seigneurin JM, De Pauw P, Pierard D, Weets I, Rebello P, Bird P, Berrie E, Frewin M, Wald- 
mann H, Bach JF, Pipeleers D, Chatenoud L: Insulin needs after CD3-antibody therapy in new-onset type 1 diabetes. $N$ Engl J Med 2005, 352:2598-2608.

43. Utset TO, Auger JA, Peace D, Zivin RA, Xu D, Jolliffe L, Alegre ML, Bluestone JA, Clark MR: Modified anti-CD3 therapy in psoriatic arthritis: a phase I/II clinical trial. J Rheumatol 2002, 29:19071913.

44. Plevy S, Salzberg B, Van Assche G, Regueiro M, Hommes D, Sandborn W, Hanauer S, Targan S, Mayer L, Mahadevan U, Frankel M, Lowder J: A phase I study of visilizumab, a humanized anti-CD3 monoclonal antibody, in severe steroid-refractory ulcerative colitis. Gastroenterology 2007, 133:1414-1422.

45. Ferrara C, Brunker P, Suter T, Moser S, Puntener U, Umana P: Modulation of therapeutic antibody effector functions by glycosylation engineering: influence of Golgi enzyme localization domain and co-expression of heterologous beta1, 4-N-acetylglucosaminyltransferase III and Golgi alpha-mannosidase II. Biotechnol Bioeng 2006, 93:851-861.

46. Kanda Y, Yamada T, Mori K, Okazaki A, Inoue M, Kitajima-Miyama K, Kuni-Kamochi R, Nakano R, Yano K, Kakita S, Shitara K, Satoh $\mathrm{M}$ : Comparison of biological activity among nonfucosylated therapeutic IgG1 antibodies with three different N-linked Fc oligosaccharides: the high-mannose, hybrid, and complex types. Glycobiology 2007, 17:104-118.

47. Davies J, Jiang L, Pan LZ, LaBarre MJ, Anderson D, Reff M: Expression of GnTIII in a recombinant anti-CD20 CHO production cell line: expression of antibodies with altered glycoforms leads to an increase in ADCC through higher affinity for FC gamma RIII. Biotechnol Bioeng 2001, 74:288-294.

48. Isaacs J, Wing M, Greenwood J, Hazleman B, Hale G, Waldmann $\mathrm{H}$ : A therapeutic human IgG4 monoclonal antibody that depletes target cells in humans. Clin Exp Immunol 1996, 106: 427-433.

49. Bindon $\mathrm{C}$, Hale G, Waldmann $\mathrm{H}$ : Importance of antigen specificity for complement mediated lysis by monoclonal antibodies. Eur J Immunol 1988, 18:1507-1514.

50. Xia M, Hale G, Waldmann H: Efficient complement-mediated lysis of cells containing the CAMPATH-1 (CDw52) antigen. Mol Immunol 1993, 30:1089-1096.

51. Stebbings R, Findlay L, Edwards C, Eastwood D, Bird C, North D, Mistry Y, Dilger P, Liefooghe E, Cludts I, Fox B, Tarrant G, Robinson J, Meager T, Dolman C, Thorpe SJ, Bristow A, Wadhwa M, Thorpe R, Poole S: "Cytokine storm" in the phase I trial of monoclonal antibody TGN1412: better understanding the causes to improve preclinical testing of immunotherapeutics. $\mathrm{J}$ Immunol 2007, 179:3325-3331.

52. Bruggemann M, Winter G, Waldmann H, Neuberger MS: The immunogenicity of chimeric antibodies. J Exp Med 1989, 170: 2153-2157.

53. Gorman SD, Clark MR: Humanisation of monoclonal antibodies for therapy. Semin Immunol 1990, 2:457-466.

54. Chung CH, Mirakhur B, Chan E, Le QT, Berlin J, Morse M, Murphy BA, Satinover SM, Hosen J, Mauro D, Slebos RJ, Zhou Q, Gold D, Hatley T, Hicklin DJ, Platts-Mills TA: Cetuximab-induced anaphylaxis and IgE specific for galactose-alpha-1,3-galactose. $N$ Engl J Med 2008, 358:1109-1117.

55. Eckardt K, Casadevall N: Pure red-cell aplasia due to anti-erythropoietin antibodies. Nephrol Dial Transplant 2003, 18:865869.

56. Mason U, Aldrich J, Breedveld F, Davis C, Elliott M, Jackson M, Jorgensen C, Keystone E, Levy R, Tesser J, Totoritis M, Truneh A, Weisman M, Wiesenhutter C, Yocum D, Zhu J: CD4 coating, but not CD4 depletion, is a predictor of efficacy with primatized monoclonal anti-CD4 treatment of active rheumatoid arthritis. $J$ Rheumatol 2002, 29:220-229.

57. Genazzani AA, Biggio G, Caputi AP, Del Tacca M, Drago F, Fantozzi R, Canonico PL: Biosimilar drugs: concerns and opportunities. BioDrugs 2007, 21:351-356.

58. Farid SS: Process economics of industrial monoclonal antibody manufacture. J Chromatogr A 2007, 848:8-18.

59. Elliott MJ, Maini RN, Feldmann M, Kalden JR, Antoni C, Smolen JS, Leeb B, Breedveld FC, Macfarlane JD, Bijl H, Woody JN: Randomised double-blind comparison of chimeric monoclonal antibody to tumour necrosis factor alpha (cA2) versus placebo in rheumatoid arthritis. Lancet 1994, 344:1105-1110.

60. Edwards J, Szczepanski L, Szechinski J, Filipowicz-Sosnowska A, Emery P, Close D, Stevens R, Shaw T: Efficacy of B-cell-tar- geted therapy with rituximab in patients with rheumatoid arthritis. N Engl J Med 2004, 350:2572-2581.

61. Maini RN, Taylor PC, Szechinski J, Pavelka K, Bröll J, Balint G Emery P, Raemen F, Petersen J, Smolen J, Thomson D, Kishimoto T; CHARISMA Study Group: Double-blind randomized controlled clinical trial of the interleukin-6 receptor antagonist, tocilizumab, in European patients with rheumatoid arthritis who had an incomplete response to methotrexate. Arthritis Rheum 2006, 54:2817-2829.

62. Genovese MC, Kaine JL, Lowenstein MB, Giudice JD, Baldassare A, Schechtman J, Fudman E, Kohen M, Gujrathi S, Trapp RG, Sweiss NJ, Spaniolo G, Dummer W; ACTION Study Group: Ocrelizumab, a humanized anti-CD20 monoclonal antibody, in the treatment of patients with rheumatoid arthritis: a phase I/II randomized, blinded, placebo-controlled, dose-ranging study. Arthritis Rheum 2008, 58:2652-2661.

63. Dorner T, Kaufmann J, Wegener W, Teoh N, Goldenberg D, Burmester G: Initial clinical trial of epratuzumab (humanized anti-CD22 antibody) for immunotherapy of systemic lupus erythematosus. Arthritis Res Ther 2006, 8:R74.

64. Keystone E, Heijde D, Mason D Jr., Landewe R, Vollenhoven RV, Combe B, Emery P, Strand V, Mease P, Desai C, Pavelka K: Certolizumab pegol plus methotrexate is significantly more effective than placebo plus methotrexate in active rheumatoid arthritis: findings of a fifty-two-week, phase III, multicenter, randomized, double-blind, placebo-controlled, parallel-group study. Arthritis Rheum 2008, 58:3319-3329.

65. Herold KC, Hagopian W, Auger JA, Poumian-Ruiz E, Taylor L, Donaldson D, Gitelman SE, Harlan DM, Xu D, Zivin RA, Bluestone JA: Anti-CD3 monoclonal antibody in new-onset type 1 diabetes mellitus. N Engl J Med 2002, 346:1692-1698.

66. Weinblatt ME, Keystone EC, Furst DE, Moreland LW, Weisman $\mathrm{MH}$, Birbara CA, Teoh LA, Fischkoff SA, Chartash EK: Adalimumab, a fully human anti-tumor necrosis factor alpha monoclonal antibody, for the treatment of rheumatoid arthritis in patients taking concomitant methotrexate: the ARMADA trial. Arthritis Rheum 2003, 48:35-45.

67. Dorner T, Burmester GR: New approaches of B-cell-directed therapy: beyond rituximab. Curr Opin Rheumatol 2008, 20:263268.

68. Furie R, Stohl W, Ginzler EM, Becker M, Mishra N, Chatham W, Merrill JT, Weinstein A, McCune WJ, Zhong J, Cai W, Freimuth W; Belimumab Study Group: Biologic activity and safety of belimumab, a neutralizing anti-B-lymphocyte stimulator (BLyS) monoclonal antibody: a phase I trial in patients with systemic lupus erythematosus. Arthritis Res Ther 2008, 10:R109.

69. Keystone EC, Genovese MC, Klareskog L, Hsia EC, Hall ST, Miranda PC, Pazdur J, Bae SC, Palmer W, Zrubek J, Wiekowski M, Visvanathan S, Wu Z, Rahman MU: Golimumab, a human antibody to TNF-\{alpha\} given by monthly subcutaneous injections, in active rheumatoid arthritis despite methotrexate: The GO-FORWARD Study. Ann Rheum Dis 2008, Dec 11. [Epub ahead of print].

70. Weinblatt ME, Kremer JM, Bankhurst AD, Bulpitt KJ, Fleischmann RM, Fox RI, Jackson CG, Lange M, Burge DJ: A trial of etanercept, a recombinant tumor necrosis factor receptor:Fc fusion protein, in patients with rheumatoid arthritis receiving methotrexate. N Engl J Med 1999, 340:253-259.

71. Genovese MC, Becker JC, Schiff M, Luggen M, Sherrer Y, Kremer J, Birbara C, Box J, Natarajan K, Nuamah I, Li T, Aranda R, Hagerty DT, Dougados M: Abatacept for rheumatoid arthritis refractory to tumor necrosis factor alpha inhibition. N Engl J Med 2005, 353:1114-1123.

72. Tak PP, Thurlings RM, Rossier C, Nestorov I, Dimic A, Mircetic V, Rischmueller M, Nasonov E, Shmidt E, Emery P, Munafo A: Atacicept in patients with rheumatoid arthritis: results of a multicenter, phase ib, double-blind, placebo-controlled, dose-escalating, single- and repeated-dose study. Arthritis Rheum 2008, 58:61-72. 